\title{
Pulmoner hipertansiyonlu hastalarda comet analizi ile değerlendirilen artmış DNA hasarı
}

\author{
Increased DNA damage with comet assay in patients with pulmonary hypertension
}

\author{
Emine Kılıç-Toprak, Yalın Tolga Yaylalı, Yasin Özdemir, Vural Küçükatay, Hande Şenol, Melek Bor- \\ Küçükatay
}

Gönderilme tarihi:23.04.2019

Kabul tarihi:05.07.2019

\section{Özet}

Amaç: Pulmoner hipertansiyonda $(\mathrm{PH})$ görülen patolojik lezyonlar, oksidatif stres ve inflamatuar süreçlerle karakterizedir. Çalışmamızın amacı, PH hastalarında DNA hasarının potansiyel katkısını araştırmaktır.

Gereç ve Yöntem: Çalışmamıza 28 tedavi almamış $\mathrm{PH}$ hastası $(59,93 \pm 11,19$ yıl) ve 28 yaş-cinsiyet uyumlu $(59,86 \pm 11,92$ yıl) sağlıklı kontrol dahil edilmiştir. Tüm hastalara tanıyı doğrulamak ve hemodinamiyi değerlendirmek için sağ kalp kateterizasyonu uygulanmıştır. Bireylerden alınan venöz kan örneklerinde, DNA hasarı belirlenmesinde tek hücre jel elektroforezi ve flüoresan mikroskopisine dayanan, onarımdan önce DNA hasarını tespit eden kuyruklu yıldız (Comet) analizi kullanılmış̧ır. Sürekli veriler ortalama \pm standart sapma (SD) olarak verilmiş, normallik testi için Shapiro-Wilk testleri kullanılmıştır. Bağımsız gruplar için Mann Whitney U testi, kategorik değişkenler için ki-kare testi kullanılmıştı. İstatistiksel analizlerde SPSS, 24.0 programı kullanılmış ve $p \leq 0,05$ değerleri istatistiksel olarak anlamlı kabul edilmiştir.

Bulgular: Ortalama pulmoner vasküler direnç 5,64 $\pm 2,99$ Wood Unitesi, ortalama sağ atriyal basınç $9,70 \pm 5,38$ $\mathrm{mmHg}$, kardiyak indeks $3,12 \pm 1,18 \mathrm{l} /$ dak / $\mathrm{m} 2$, mixed venöz $\mathrm{O} 2$ saturasyonu $\% 64,77 \pm 13,33$ olarak saptanmıştır. DNA hasar parametrelerinden, kuyruk uzunluğu $(24,02 \pm 11,34$ ve $16,88 \pm 3,55 \mu \mathrm{m}, p=0,0001)$, kuyruk momenti $(1,93 \pm 2,36$ ve $0,87 \pm 1,03 \mu \mathrm{m}, p=0,013)$, kuyruk göçü $(10,3 \pm 12,24$ ve $3,62 \pm 2,75, p=0,03)$ hastalarda istatistiksel olarak anlamlı düzeyde yüksek saptanmıştır.

Sonuç: Bulgularımız, PH hastalarında DNA tamir mekanizmaları devreye girmeden önce DNA hasarının artmış olabileceğini göstermektedir. DNA hasarı PH patofizyolojisine katkıda bulunabilir ve/veya $\mathrm{PH}$ 'da yeni bir farmakolojik hedef olarak ele alınabilir.

Anahtar Kelimeler: Pulmoner hipertansiyon, DNA hasarı, Comet analizi.

Kılıç Toprak E, Yaylalı YT, Özdemir Y, Küçükatay V, Şenol H, Bor Küçükatay ZM. Pulmoner hipertansiyonlu hastalarda comet analizi ile değerlendirilen artmış DNA hasarı. Pam Tıp Derg 2019;12:415-421.

\footnotetext{
Abstract

Purpose: In pulmonary hypertension $(\mathrm{PH})$, pathologic lesions are characterized by oxidative stress and inflammatory processes. The purpose of our study was to investigate the potential contribution of DNA damage in $\mathrm{PH}$.

Materials and methods: The study comprised 28 treatment-naive $\mathrm{PH}$ patients $(59.93 \pm 11.19$ years) and 28 ageand sex-matched $(59.86 \pm 11.92$ years) healthy controls. All participants underwent a right-heart catheterization to confirm the diagnosis and to asses hemodynamics. Venous blood was obtained from participants. DNA damage were evaluated using the comet assay which is based on single cell gel electrophoresis and fluorescent microscopy and detects DNA damage prior to repair. Continuous data were reported as mean \pm standard deviation (SD). Shapiro-Wilk tests were used for testing normality. Mann Whitney $U$ test was used for independent groups. For categorical variables, Chi-square test was used. SPSS, 24.0 was used for statistical analyses and $p$ value less than 0.05 was considered statistically significant.

Results: The average pulmonary vascular resistance was $5.64 \pm 2.99 \mathrm{WU}$, mean right atrial pressure was $9.70 \pm 5.38 \mathrm{mmHg}$, cardiac index was $3.12 \pm 1.18 \mathrm{l} / \mathrm{min} / \mathrm{m} 2$, mixed venous $\mathrm{O} 2$ saturation was $64.77 \pm 13.33 \%$. DNA damage parameters such as tail length $(24.02 \pm 11.34$ vs. $16.88 \pm 3.55 \mu \mathrm{m}, p=0.0001)$, tail moment $(1.93 \pm 2.36$ vs.

Emine Kılıç-Toprak, Dr. Öğr. Üyesi. Pamukkale Üniversitesi, Tıp Fakültesi, Fizyoloji Anabilim Dalı, DENiZLi, e-posta: ektoprak@pau.edu.tr (orcid.org/0000-0002-8795-0185) (Sorumlu yazar)

Yalın Tolga Yaylalı, Doç. Dr. Pamukkale Üniversitesi, Tıp Fakültesi, Kardiyoloji Anabilim Dalı, DENiZLi, e-posta: ytyaylali@pau.edu.tr (orcid. org/0000-0002-8452-923X)

Yasin Özdemir, Arş. Gör. Pamukkale Üniversitesi, Tıp Fakültesi, Fizyoloji Anabilim Dalı, DENizLi, e-posta: yozdemir@pau.edu.tr (orcid org/0000-0002-7562-0744)

Vural Küçükatay, Prof. Dr. Pamukkale Üniversitesi, Tıp Fakültesi, Fizyoloji Anabilim Dalı, DENiZLí, e-posta: vkucukatay@pau.edu.tr (orcid. org/0000-0002-6850-6281)

Hande Şenol, Öğr. Gör. Pamukkale Üniversitesi, Tıp Fakültesi, Biyoistatistik Anabilim Dalı, DENiZLí, e-posta: hsenol@pau.edu.tr (orcid. org/0000-00016395-7924)

Melek Bor-Küçükatay, Prof. Dr. Pamukkale Üniversitesi, Tıp Fakültesi, Fizyoloji Anabilim Dalı, DENiZLi, e-posta: mbor@pau.edu.tr (orcid. org/0000-0002-9336-0205)
} 
$0.87 \pm 1.03 \mu \mathrm{m}, p=0.013)$, tail migration $(10.3 \pm 12.24$ vs. $3.62 \pm 2.75, p=0.03)$ were significantly higher in patients with $\mathrm{PH}$.

Conslusion: These results suggest that patients with $\mathrm{PH}$ could have increased DNA damage before DNA repair mechanisms are at play. DNA damage could be contributing to the pathophysiology and may represent a novel pharmacological target in $\mathrm{PH}$.

Key Words: Pulmonary hypertension, DNA damage, Comet analysis.

Kılıç Toprak E, Yaylalı YT, Özdemir Y, Küçükatay V, Şenol H, Bor Küçükatay ZM. Increased DNA damage with comet assay in patients with pulmonary hypertension. Pam Med J 2019;12:415-421.

\section{Giriş}

Pulmoner hipertansiyon (PH), çoğunlukla tanısı geç konan, sağ kalp yetmezliği nedeniyle erken yaşta ölüme neden olabilen, ortalama pulmoner arter basıncında (OPAB) ve pulmoner vasküler dirençte (PVD) artışla karakterize yıkıcı bir hastalıktır [1, 2]. PH'da pulmoner arter düz kas hücrelerinde proliferasyon/apoptozis dengesizliği, distal pulmoner arterlerde obstrüktif vasküler lezyonlar ve ayrıca prekapiller pulmoner arteriyollerde vasküler yeniden şekillenme gözlenmektedir [3-5]. PH patogenezi net olarak bilinmemekle birlikte, epigenetik deregülasyon, inflamasyon, DNA hasarı gibi pekçok farklı çevresel streslerle tetiklenebildiği düşünülmektedir [5]. PH, etyolojisine göre; pulmoner arteryel hipertansiyon (PAH), sol kalp hastalığı nedenli $\mathrm{PH}$; akciğer hastalıklarına ve/veya hipoksiye bağlı $\mathrm{PH}$; pulmoner arter obstrüksiyonuna bağlı $\mathrm{PH}$ ve mekanizmaları belirsiz ve/veya çok faktörlü $\mathrm{PH}$ olarak 5 alt gruba ayrılmaktadır $[6,7]$.

Günümüze kadar yapılan literatür taraması sonucunda, PH etyolojisinde DNA hasarının gösterildiği sınırlı sayıda çalışma olduğu ve bu çalışmalarda kullanılan DNA hasarı ölçüm yöntemlerinin farklı olduğu belirlenmiştir [8, 9]. PAH'lı olguların distal pulmoner arterlerinde, DNA hasar belirteçlerinde artı̧̧ belirlenmiştir [8]. Yine benzer bir çalışmada hem pulmoner arter endotel hücrelerinde, hem de periferik kanda mononükleer hücrelerde $\mathrm{PAH}$ ile DNA hasarında sağlıklılara göre anlamlı artışlar belirlenmiş ve aynı zamanda DNA hasarının ROS üretimiyle korele olduğu gösterilmiştir [9]. Literatürde $\mathrm{PH}$ 'li hastalarda Comet analizi kullanılarak DNA hasarı araştıran bir çalışmaya rastlanmamıştır. Comet testi ile DNA hasarının kantitatif olarak saptanması için; kuyruk uzunluğu, kuyruk yoğunluğu ve kuyruk momenti parametreleri sıkça kullanılmaktadır. Kuyruk uzaması hasar ile doğru orantılı olup, kuyruktaki floresan yoğunluğu ve kuyruk momenti de DNA hasarı derecesi ile paralel olarak değişmektedir. Comet (kuyruklu yıldız) yöntemi uygulaması kolay, fizikel ve kimyasal etkenlerin genotoksik ve sitotoksik etkilerini inceleyebilen önemli bir metottur [10].

Yukarıdaki bilgiler ışığında, PH'li hastalarda Comet yöntemiyle değerlendirilen DNA hasar parametrelerinde artış olur" şeklindeki hipotezimizi değerlendirmek üzere, $\mathrm{PH}$ 'li olgularda periferik lökositlerde Comet analiziyle DNA hasarının incelenmesi amaçlanmıştır. Çalışmadan elde edilen verilerin $\mathrm{PH}$ patogenezine katkı sağlayacağı düşünülmektedir.

\section{Gereç ve yöntem}

Araştırmamıza, Pamukkale Üniversitesi Tıp Fakültesi Kardiyoloji AD'na PH ön tanısı ile başvuran ve sağ kalp kateterizasyonu yapılan hastalardan prekapiller $\mathrm{PH}$ tanı kriterlerini karşılayan bireyler çalışmaya dahil edilmiştir. $\mathrm{PH}$ tanısı için sağ kalp kateterizasyonu yapılan ve sonucunda OPAB'ın $\geq 25 \mathrm{mmHg}$, pulmoner kapiller uç basıncının $\leq 15 \mathrm{mmHg}$ ve PVD'nin $\geq 3$ Wood ünitesinden büyük saptanması esas alınmıştır [11]. PH tanısı alıp, sol kalp, akciğer ve majör bir hastalığı olan (Grup 2, 3, 5) olgular araştırmaya dahil edilmemiştir. Kontrol grubu, yaş ve cinsiyet uygun bireylerden dahiliye polikliniğine rutin yıllık kontrole gelen dışlama kriterleri olmayan sağlıklı gönüllülerden oluşmuştur. Fonksiyonel sınıf değerlendirmesi için World Health Organization (WHO) fonksiyonel sınıfı (FS) (New York Heart Association [NYHA] fonksiyonel sınıfın bir modifikasyonu) kullanılmıştır.

Çalışma öncesinde bireylerin her birine çalışma ile ilgili karşılaşılabilecek risk ve rahatsızlıkları içeren yazııı ve sözlü ayrıntılı bilgi verilmiş, onam alınmıştır. Çalışma için etik kurul izni (10.11.2015 tarih ve 19 sayılı kurul toplantısında, 60116787-020/65509 sayılı 
başvuru) alınmıştır. Deneklerden rutin kan tetkikleri esnasında, yaklaşık 15'er ml venöz kan alınmıştır. Alınan kanlar uygun taşıma koşulları sağlanarak uygun sürede Tıp Fakültesi Fizyoloji $A D$ laboratuvarına ulaştırılmıştır. Comet analizi için kan EDTA'lı tüplere alınmış, aynı gün taze kandan lenfosit izolasyonu yapılmış, örnekler analizin yapılacağı güne kadar $-80^{\circ} \mathrm{C}$ 'de saklanmıştır.

1-DNA Hasarı Ölçümü (Alkali Comet Analizi): Bireylerden pıhtılaşması engellenmiş kan $5 \mathrm{ml}$ bir tüpe alınarak 1:1 oranında izotonik fosfat tamponu (PBS) ile seyreltilmiştir. Bu 10 ml'lik seyreltilmiş kan içine $3 \mathrm{ml}$ Ficol-1077 konmuş bir başka tüpe aktarılarak 400g'de 20 dakika santrifüj işlemine tabi tutulmuştur. Santrifüjden sonra elde edilen pellet $1 \mathrm{ml}$ RPMI ile 2-3 kez yıkandıktan sonra, Hemositometre ile sayılmış ve 100 mikrolitrede $2 \times 10^{4}$ hücre olacak şekilde ayarlanmıştır. Bu şekilde hazırlanmış lenfosit süspansiyonundan 80 mikrolitre alınarak 100 $\mu \mathrm{l} \% 0,5^{\prime} \mathrm{lik} \mathrm{Ca}^{2+}$ ve $\mathrm{Mg}^{+}$içermeyen PBS (fosfat tampon tuzu) ile $37^{\circ} \mathrm{C}$ 'de hazırlanan "Low melting agaroz" (LMA) ile resüspanse edilmiştir. Bu LMA+hücre karışımı önceden \%1'lik "normal melting" agaroz (NMA) ile kaplanmış olan lam üzerine ince bir tabaka halinde dökülmüş ve 30 dk buz üzerinde beklendikten sonra 3. tabaka olarak $70 \mu \mathrm{l} \% 0,5$ 'lik LMA ile kaplanmış ve tekrar 10 dakika buz üzerinde bekletilmiştir. Daha sonra lam hücresel proteinleri uzaklaştırmak amacıyla, pH'ı 10 olan soğuk lizis bağlama tamponu ile 60 dakika boyunca $+4^{\circ} \mathrm{C}$ 'de muamele edilmiştir. Lizis işlemi sonrası lamlar yatay jel elektroforezine aktarılmış ve yeni hazırlanmış alkalin elektroforez tamponunda 30 dakika süre ile inkübe edilmiştir. Bu sürenin sonunda lamlar yatay elektroforez tankına konularak $+4^{\circ} \mathrm{C}^{\prime}$ de, $300 \mathrm{~mA}$ ' de akım altında 30 dakika boyunca elektroforez işlemine tabi tutulmuştur. Elektroforez işlemini takiben, lamlar nötralizasyon tamponu $(0,4 \mathrm{M}$ Tris- $\mathrm{HCl}$, $\mathrm{pH} 7,5$ ) ile alkalin ve deterjanları uzaklaştırmak amacıyla 3 kez 5 dakika $+4^{\circ} \mathrm{C}$ 'de yıkanmıştır. Nötralizasyon işlemi sonrası lamlar $60 \mu \mathrm{l}$ etidyum bromid $(2 \mu \mathrm{l} / \mathrm{ml})$ ile boyanarak flüoresan mikroskobunda incelenmiş, olası DNA hasarı "Comet assay IV system (AutoComet)" program yazılımıyla değerlendirilmiştir.

Hasar değerlendirilmesinde yazılım aracılığı ile HL (baş uzunluğu, $\mu \mathrm{m}$ ), TL (kuyruk uzunluğu, $\mu \mathrm{m}$ ), baş yoğunluğu (baş kısmındaki DNA yüzdesi, \%H-DNA olarak ifade edilir), kuyruk yoğunluğu (kuyruk kısmındaki DNA yüzdesi, \%T-DNA olarak ifade edilir), kuyruk momenti (TM, $\mu \mathrm{m}$ olarak ifade edilir, \%T-DNA ile TL'nin çarpımının 100'e bölünmesi ile edilen bir değerdir), kuyruk migrasyonu (baş kısmının kenarından küçük saptanabilir fragmana DNA göçünün uzunluğudur) parametreleri kullanılmıştır $[10,12]$.

2-Sağ Kalp Kateterizasyonu: Standart Judkins tekniği ile antegrad internal jugular veya femoral yoldan girilerek yapılmış, herhangi bir medikasyon kullanılmamıştır. Hemodinamik ölçümler için Swan-Ganz kateteri kullanılmıştır. Sağ atriyum, sağ ventrikül, pulmoner arter ve pulmoner kapiller uç (PKUB) basınçları ölçülmüştür. Oksijen satürasyon ölçümleri için kan örnekleri superior vena kava ve pulmoner arterden alınmıştır. PVD, PVD = ort PABPKUB/pulmoner akım (Qp) formülü kullanılarak hesaplanmıştır. Qp, Fick metodu kullanılarak belirlenmiştir [13]. Klinik özellikleri nedeni ile endike olduğu zaman sol kalp kateterizasyonu ve koroner arteriografi yine Judkins tekniği kullanılarak yapılmıştır. Sol ventrikül diastol sonu basıncı pigtail kateteri sol ventriküle ilerletilerek ölçülmüştür.

\section{İstatistiksel Analiz}

Referans olarak yapılmış olan benzer çalışma bulunmadığından beklentiler yönünde kuvvetli düzeyde etki büyüklüğü $(\mathrm{d}=0,7)$ elde edilebileceği düşünülerek yapılan güç analizi sonucunda çalışmaya toplam 52 kişi (her grup için en az 26 kişi) alındığında \%95 güven düzeyinde $\% 80$ güç elde edilebileceği hesaplanmıştır. $\mathrm{Bu}$ bilgiler doğrultusunda 28 kişi $\mathrm{PH}$ grubunda, 28 kişi de kontrol grubunda olacak şekilde çalışmaya 56 kişi dahil edilmiştir. $\mathrm{Bu}$ kişilerden elde ettiğimiz değerlerin etki büyüklüğü incelendiğinde kuvvetli düzeyde bir etki büyüklüğü $(\mathrm{d}=0,85)$ elde edildiği görülmüştür. $\mathrm{Bu}$ etki büyüklüğü düzeyi için çalışmamızın $\% 95$ güven düzeyinde $\% 93$ güce ulaştığı hesaplanmıştır. Veriler SPSS 24,0 (IBM SPSS Statistics 24 software (Armonk, NY: IBM Corp.)) paket programıly analiz edilmiştir. Sürekli değişkenler ortalama \pm standart sapma ve kategorik değişkenler sayı ve yüzde olarak ifade edilmiştir. Verilerin normal dağılıma uygunluğu Shapiro-Wilk testi ile incelenmiştir. Bağımsız grup farklılıkların karşılaştırımasında 
Mann-Whitney $U$ testi kullanılmıştır. Kategorik değişkenler arasındaki farklılıklar ise Ki kare analizi ile incelenmiştir. Tüm analizlerde $p<0,05$ istatistiksel olarak anlamlı kabul edilmiştir.

\section{Bulgular}

Çalışmamıza toplam $28 \mathrm{PH}$ hastası $(59,93 \pm 11,19$ yıl) ile yaş ve cinsiyet uyumlu 28 sağlıklı birey $(59,86 \pm 11,92$ yıl) dahil edilmiştir. 11 hasta WHO FS II, 14 hasta WHO FS III ve 3 hasta WHO FS IV olarak değerlendirilmiştir. Ortalama pulmoner vasküler rezistans (PVR)
5,64 $\pm 2,99$ Wood ünitesi, ortalama sağ atriyum basıncı (mRAP) 9,70 $\pm 5,38 \mathrm{mmHg}$, kardiyak indeks (Cl) $3,12 \pm 1,18 \mathrm{l} / \mathrm{dk} / \mathrm{m}^{2}$, miks venöz $\mathrm{O}_{2}$ saturasyonu $\left(\mathrm{Svo}_{2}\right) \% 64,77 \pm 13,33$ olarak bulunmuştur. DNA hasarı incelendiğinde $\mathrm{PH}$ hastalarında kuyruk uzunluğu, kuyruk momenti ve kuyruk migrasyonu değerleri kontrol grubuna göre istatistiksel olarak anlamlı derecede yüksek saptanmıştır (sırasıyla $p=0,0001, \quad p=0,013$ ve $p=0,03)$. Baş uzunluğu, baş yoğunluğu ve kuyruk yoğunluğu parametrelerinde ise hasta ve kontrol arasında anlamlı bir fark saptanmamıştır (Tablo 1).

Tablo 1. Pulmoner hipertansiyon hasta ve kontrol gruplarının DNA hasarı parametreleri.

\begin{tabular}{|c|c|c|c|}
\hline & $\begin{array}{l}\text { Kontrol grubu } \\
\qquad(n=28)\end{array}$ & $\begin{array}{l}\text { Pulmoner hipertansiyon } \\
\qquad(\mathrm{n}=28)\end{array}$ & $p$ \\
\hline \multicolumn{4}{|c|}{ Comet Analizi sonuçları } \\
\hline Baş uzunluğu ( $\mu \mathrm{m})$ & $27,13 \pm 4,63$ & $29,22 \pm 9,53$ & 0,33 \\
\hline Kuyruk Uzunluğu ( $\mu \mathrm{m})$ & $16,88 \pm 3,55$ & $24,02 \pm 11,34$ & $0,0001^{*}$ \\
\hline Baş yoğunluğu (\%) & $90,86 \pm 7,91$ & $84,98 \pm 13,24$ & 0,123 \\
\hline Kuyruk Yoğunluğu (\%) & $9,14 \pm 7,91$ & $15,02 \pm 13,24$ & 0,123 \\
\hline Kuyruk momenti $(\mu \mathrm{m})$ & $0,87 \pm 1,03$ & $1,93 \pm 2,36$ & $0,013^{*}$ \\
\hline Kuyruk migrasyonu $(\mu \mathrm{m})$ & $3,62 \pm 2,75$ & $10,3 \pm 12,24$ & $0,03^{*}$ \\
\hline
\end{tabular}

Değerler ortalama \pm standart sapma olarak belirtilmiştir. " $p<0,05$ :kontrol grubundan fark.

\section{Tartışma}

PH hastalarında olası DNA hasarını incelemek amacıyla planladığımız çalışma, PH'de periferik kan hücrelerinden Comet analizi kullanılarak hasarı araştıran literatürdeki ilk araştırmadır. Çalışmamızın ana sonucu olarak, $\mathrm{PH}$ hastalarında kuyruk uzunluğu, kuyruk momenti ve kuyruk migrasyonu değerleri kontrol grubuna göre anlamlı derecede yüksek saptanmıştır. Bulgularımız, PH hastalarında DNA hasarının artmış olduğunu göstermektedir.

PH'nin altında yatan moleküler mekanizmalar tam olarak anlaşılamamış, PH'nin erken evrelerinde, oksidatif stresin ve inflamasyonun, vaskülerhücrelerdekasılabilirliğiveproliferasyonu arttırarak, vasküler yeniden şekillenmeye önemli katkı sağladığı gösterilmiştir [14, 15]. Alveoler hipoksi; pulmoner vazokonstrüksiyon için güçlü bir uyarandır. Vazokonstrüksiyonun devamlı hale gelmesi ve özellikle distal pulmoner arterlerde progresif vasküler yeniden şekillenmeye yol açması, pulmoner vasküler direnci arttırarak ve ortalama pulmoner arter basıncının dinlenimde
25 mmHg'nın üzerine çıkmasına neden olarak PH'ye zemin hazırlamaktadır [16, 17]. Kronik veya ciddi hipoksi, antioksidan ve oksidan kapasiteler arasında da dengesizliğe yol açabilmektedir [18]. Alveoler hipoksi ile ayrıca DNA tamir mekanizmalarının baskılandığı ve özellikle aktif olan proliferatif hücrelerde mutagenez oranının arttığı bildirilmiştir [19]. DNA replikasyonu sırasında, oksidatif stres, radyasyon ve kronik inflamasyon gibi çevresel faktörler tarafından hatalı DNA dizilimlerinin olabildiği ileri sürülmektedir [20]. DNA'da oluşan hasarlar doğru bir şekilde tamir edilemezse, mutasyonlara ve apoptozise yol açabilir [21].

Tek hücre jel elektroforezi veya sıklıkla tercih edilen diğer adıyla "Comet (kuyruklu yıldız) Assay" yöntemi son yıllarda genişleyen uygulama alanı, güvenilirliği ve uygulamasının kolay olması bakımından kimyasal ve fiziksel etmenlerin canlılar üzerinde yol açtığı genotoksik ve sitotoksik etkilerin bir göstergesi olan DNA hasar seviyelerinin ölçülmesi için tercih edilen önemli bir metottur [10]. Araştırıcı 
tarafından seçilen Cometler için çeşitli flüoresan parametreleri hesaplayacak çok sayıda yazılım bulunmaktadır. Bu yazılımlar ile DNA parçaları baş ve kuyruk olarak iki ana bölüme ayrılmakta, çeşitli parametreler hesaplanabilmektedir. Kuyruk uzunluğu ve kuyruk yoğunluğunun DNA hasarı ile doğru orantılı olduğu bilinmektedir. Comet analizi kapsamında DNA hasarı, granülositler içinde yarı ömrü en uzun hücre olan lenfositlerin izolasyonu ile incelenmektedir.

DNA hasarının etkin olarak belirlenmesi ve onarılması hücrelerin sağ kalımları için çok önemlidir. Hipoksiye yanıt olarak, pulmoner arter endotel hücre disfonksiyonlarının belirlenmesi DNA hasarının erken belirteci sayılabilmektedir [22, 23]. Ayrıca hastalığın başlangıç (hafif) evresinde rol alan pek çok patogenetik sürecin ciddi $\mathrm{PH}$ 'de de rol aldığı gösterilmiş ancak henüz moleküler süreçlerin hastalığın ilerlemesini ve hastalığın ciddiyetini nasıl belirlediği netleşmemiştir. PH'nin altında yatan genetik varyasyonlar ve mutasyonların araştırılmasının yanında, mümkün olduğunda akciğer dokusunun ve/veya özel hücre tiplerinin ve/veya dolaşımdaki kan hücrelerinin moleküler incelemesi, hastalığa ilişkin mekanizmalarla ilgili önemli bilgiler sağlayabilecektir [24]. Çalışmaya WHO FS II $(n=11)$, WHO FS III $(n=14)$ ve WHO FS IV ( $n=3) \mathrm{PH}$ hastası dahil edilmiştir. $\mathrm{PH}$ hastalarında periferik lenfositlerden Comet analizi ile tespit edilen kuyruk uzunluğunun artmış olması DNA kırıklarının artmış olduğunun ve ayrıca kuyruktaki floresan yoğunluğu ve kuyruk momentinin artması da bunlara paralel olarak DNA hasarının da artmış olduğunun göstergesidir. Gözlemlenen bu değişikliklerin, hastalığın ciddiyeti veya ilerlemiş olmasıyla ilişkili olabileceği ileri sürülebilir. Hastalığın şiddetinin artmasıyla birlikte DNA hasar tamir mekanizmalarının düzgün çalışmaması, DNA hasarı varlığında hastalığın patofizyolojisine katkıda bulunuyor olabilir.

Hastalığın başlangıç aşamasında ve ilerlemesinde, pulmoner inflamasyon, pulmoner vasküler yeniden şekillenme ve bunların DNA hasarındaki rollerinin net olarak anlaşılması, yeni tanı ve tedavi yöntemlerinde yol gösterici olabilecektir [25]. Literatürde PH'li hastaların akciğer hücrelerinde ve kan hücrelerinde DNA hasarının artmış olduğunu bildiren az sayıda çalışma bulunmaktadır [8, 9, 23, 26]. $\mathrm{Bu}$ çalışmalarda, hasarın ne zaman ve nasıl oluştuğu, hastalığın patogenezindeki rolü kesinlik kazanmamıştır. Federici ve ark. PAH'ın son aşamasında sadece akciğere özgül, pulmoner arter endotel hücrelerinde görülen DNA hasarında değil, aynı zamanda periferik kan hücrelerinde de DNA hasarının bazal seviyelerinde benzer bir artış göstermişlerdir [9]. Ayrıca, PAH'lı hastalarda DNA hasarına karşı duyarlılığın artmış olabileceği ileri sürülmüştür [9]. PH'da oksidatif stres anormallikleri, mitokondri sayısında, oksijen duyarlılığında ve redoks dengesinde değişimler de belirlenmiştir [27-29]. Federici ve ark.'nın çalışması, literatürde $\mathrm{PAH}$ hücrelerinde ROS üretimindeki artışla DNA hasarı seviyesindeki artışın direk ilişkili olduğunu gösteren ilk çalışmadır [9]. Ortalama ROS üretiminde artış olması ve böylece DNA hasarı oluşması, $\mathrm{PH}$ için bir risk faktörü olabilir, çünkü pulmoner arter endotelyal hücrelerinde bir genomik hasar oluşabilir ve bu da endotelyal hasar sonrası hiperproliferasyonla karakterizedir [9]. Bizim çalışmamızda da literatür verilerine benzer şekilde, $\mathrm{PH}$ ile bireylerin lökositlerinde; kuyruk uzunluğu, kuyruk momenti ve kuyruk migrasyonu gibi DNA hasar parametrelerinde artış belirlenmiştir.

PH'nin genetik temeline devam eden ilgi hastalığın anlaşılmasını arttıracaktır. Çeşitli genetik, moleküler, biyokimyasal ve çevresel faktörler PH'nin etyolojisinin açıklanmasına katkı sağlayabilecekleri gibi, hastalığın alevlenme dönemiyle ilişkili de olabilirler [25]. Aşırı hücresel cevap; kronik inflamatuar süreç, genetik anormallikler patoloji ile ilişkili faktörlerdir. Hastalığın farklı formlarında altta yatan pulmoner arter ve venlerdeki patolojik değişikliklerin anlaşılmasında temel boşluklar varlığını sürdürmektedir [25]. Yaşlanmayla birlikte, fizyolojik fonksiyonların azaldığı ve DNA hasarına yatkınlığın arttığı iyi bilinmektedir [30, 31]. Bizim çalışmamızda da yukarıda bahsedilen verilere benzer şekilde, hastalarımızın yaşları $59,93 \pm 11,19$ yıl şeklindeydi. DNA hasarı tamir mekanizmalarının yaşla beraber azalmış olması da ileri sürülebilen mekanizmalardandır. Bulgularımız, PH'nin ilerlemesiyle birlikte, genotoksisitenin artmış olduğu ve DNA tamir mekanizmalarının koruyucu etki oluşturamadığını destekler niteliktedir.

Sonuç olarak, bulgularımız PH'li hastalarda periferik kan hücrelerinde, DNA hasarı oluştuğunu göstermektedir. Çalışmamız konu ile ilgili bir ön çalışma niteliğinde değerlendirilebilir. PH'de ana sorunlar, pulmoner vasküler patoloji şeklindedir. Moleküler sinyal yolağındaki anormalliklerin hangi mekanizmalarla vasküler 
yeniden şekillenmeye neden olarak DNA hasarına yol açabildiği halen araştırma konusudur. Ayrıca, PH'li bireylerin DNA tamir mekanizmalarının normal olarak işlev yapıp yapmadığının da belirlenmesi gereklidir. Gen seviyesinde DNA hasarının ve tamir mekanizmalarının araştırılması konunun netleştirilmesine katkı sağlayabilecektir.

Çıkar İlişkisi: Yazarlar çıkar ilişkisi olmadığını beyan eder.

\section{Kaynaklar}

1- Rich S, Dantzker DR, Ayres SM, et al. Primary pulmonary hypertension. A national prospective study. Ann Intern Med 1987;107:216-223.

2- McLaughlin VV, Archer SL, Badesch DB, et al. ACCF/AHA 2009 expert consensus document on pulmonary hypertension: A report of the American College of Cardiology Foundation Task Force on Expert Consensus Documents and the American Heart Association: Developed in collaboration with the American College of Chest Physicians, American Thoracic Society, Inc. and the Pulmonary Hypertension Association. Circulation 2009;119:2250-2294. https:// dx.doi.org/10.1161/CIRCULATIONAHA.109.192230

3- Kishimoto $\mathrm{Y}$, Kato $\mathrm{T}$, Ito $\mathrm{M}$, et al. Hydrogen ameliorates pulmonary hypertension in rats by anti-inflammatory and antioxidant effects. J Thorac Cardiovasc Surg 2015;150:645-654. https://dx.doi.org/10.1016/j. jtcvs.2015.05.052

4- Cool C, Kennedy D, Voelkel N, Tuder R. Pathogenesis and evolution of plexiform lesions in pulmonary hypertension associated with scleroderma and human immunodeficiency virus infection. Hum Pathol 1997;28:434-442.

5- Vaillancourt M, Ruffenach G, Meloche J, Bonnet S. Adaptation and remodelling of the pulmonary circulation in pulmonary hypertension. Can J Cardiol 2015;31:407415. https://dx.doi.org/10.1016/j.cjca.2014.10.023

6- Galiè N, Hoeper MM, Humbert M, et al. Guidelines for the diagnosis and treatment of pulmonary hypertension: The Task Force for the Diagnosis and Treatment of Pulmonary Hypertension of the European Society of Cardiology (ESC) and the European Respiratory Society (ERS), endorsed by the International Society of Heart and Lung Transplantation (ISHLT). Eur Heart J 2009;30:2493-2537. https://dx.doi.org/10.1093/ eurheartj/ehp297
7- McLaughlin VV, Archer SL, Badesch DB, et al. ACCF/AHA 2009 expert consensus document on pulmonary hypertension a report of the American College of Cardiology Foundation Task Force on Expert Consensus Documents and the American Heart Association developed in collaboration with the American College of Chest Physicians; American Thoracic Society, Inc; and the Pulmonary Hypertension Association. J Am Coll Cardiol 2009;53:1573-1619. https://dx.doi.org/10.1016/j.jacc.2009.01.004

8- Meloche J, Pflieger A, Vaillancourt M, et al. Role for DNA damage signaling in pulmonary arterial hypertension. Circulation 2014;129:786-797. https:// dx.doi.org/10.1161/CIRCULATIONAHA.113.006167

9- Federici C, Drake KM, Rigelsky CM, et al. Increased mutagen sensitivity and DNA damage in pulmonary arterial hypertension. Am J Respir Crit Care Med 2015;192:219-228. https://dx.doi.org/10.1164/ rccm.201411-21280C

10- Nandhakumar S, Parasuraman S, Shanmugam MM, Rao KR, Chand P, Bhat BV. Evaluation of DNA damage using single-cell gel electrophoresis (Comet Assay). J Pharmacol Pharmacother 2011;2:107-111. https:// dx.doi.org/10.4103/0976-500X.81903

11- Galiè N, Humbert M, Vachiery JL, et al. 2015 ESC/ ERS Guidelines for the diagnosis and treatment of pulmonary hypertension: The Joint Task Force for the Diagnosis and Treatment of Pulmonary Hypertension of the European Society of Cardiology (ESC) and the European Respiratory Society (ERS): Endorsed by: Association for European Paediatric and Congenital Cardiology (AEPC), International Society for Heart and Lung Transplantation (ISHLT). Eur Heart J 2016;37:67119. https://dx.doi.org/10.1093/eurheartj/ehv317

12- Dikilitaş $M$, Koçyiğit $A$. Canlılarda "tek hücre jel elektroforez" yöntemi ile DNA hasar analizi (teknik not): COMET analiz yöntemi. Harran Tarım ve Gıda Bilimleri Dergisi 2010;14,77-89.

13- Davidson CJ, Bonow RO. Cardiac Catheterization. In: Mann DL, Zipes DP, Libby P, et al, ed. Braunwald's Heart Disease. Philadelphia, PA, Elsevier 2015;378.

14- Rabinovitch M, Guignabert $C$, Humbert M, Nicolls MR. Inflammation and immunity in the pathogenesis of pulmonary arterial hypertension. Circ Res 2014;115:165-175. https://dx.doi.org/10.1161/ CIRCRESAHA.113.301141

15- Intengan HD, Schiffrin EL. Vascular remodeling in hypertension: Roles of apoptosis, inflammation, and fibrosis. Hypertension 2001;38:581-587.

16- Stenmark KR, Fagan KA, Frid MG. Hypoxia-induced pulmonary vascular remodeling: Cellular and molecular mechanisms. Circ Res 2006;99:675-691. https://dx.doi. org/10.1161/01.RES.0000243584.45145.3f 
17- Bourgeois A, Omura J, Habbout K, Bonnet S, Boucherat O. Pulmonary arterial hypertension: New pathophysiological insights and emerging therapeutic targets. Int J Biochem Cell Biol 2018;104:9-13. https:// dx.doi.org/10.1016/j.biocel.2018.08.015

18- Chen PI, Cao A, Miyagawa K, et al. Amphetamines promote mitochondrial dysfunction and DNA damage in pulmonary hypertension. JCI Insight 2017;2:e90427. https://dx.doi.org/10.1172/jci.insight.90427

19- Bristow RG, Hill RP. Hypoxia and metabolism. Hypoxia, DNA repair and genetic instability. Nat Rev Cancer 2008;8:180-192. https://dx.doi.org/10.1038/nrc2344

20- Ranchoux B, Meloche J, Paulin R, Boucherat O, Provencher S, Bonnet S. DNA damage and pulmonary hypertension. Int J Mol Sci 2016;17:990. https://dx.doi. org/10.3390/ijms17060990

21- Lodish H, Berk A, Zipursky SL, Matsudaira P, Baltimore $\mathrm{D}$, Darnell J. DNA damage and repair and their role in carcinogenesis. In: Molecular Cell Biology; WH. Freeman: New York, NY, USA, 2000.

22- Diebold I, Hennigs JK, Miyagawa K, et al. BMPR2 preserves mitochondrial function and DNA during reoxygenation to promote endothelial cell survival and reverse pulmonary hypertension. Cell Metab 2015;21:596-608. https://dx.doi.org/10.1016/j. cmet.2015.03.010

23- Li M, Vattulainen $\mathrm{S}$, Aho $\mathrm{J}$, et al. Loss of bone morphogenetic protein receptor 2 is associated with abnormal DNA repair in pulmonary arterial hypertension. Am J Respir Cell Mol Biol 2014;50:11181128. https://dx.doi.org/10.1165/rcmb.2013-03490C

24- Soubrier F, Chung WK, Machado R, et al. Genetics and genomics of pulmonary arterial hypertension. Turk Kardiyol Dern Ars 2014;42:17-28.

25- Tuder RM, Archer SL, Dorfmüller P, et al. Relevant issues in the pathology and pathobiology of pulmonary hypertension. J Am Coll Cardiol 2013;62:D4-12. https:// dx.doi.org/10.1016/j.jacc.2013.10.025

26- de Jesus Perez VA, Yuan K, Lyuksyutova MA, et al. Whole-exome sequencing reveals TopBP1 as a novel gene in idiopathic pulmonary arterial hypertension. Am J Respir Crit Care Med 2014;189:1260-1272. https:// dx.doi.org/10.1164/rccm.201310-17490C

27- Bowers R, Cool C, Murphy RC, et al. Oxidative stress in severe pulmonary hypertension. Am J Respir Crit Care Med 2004;169:764-769. https://dx.doi.org/10.1164/ rccm.200301-1470C

28- Xu W, Koeck T, Lara AR, et al. Alterations of cellular bioenergetics in pulmonary artery endothelial cells. Proc Natl Acad Sci USA 2007;104:1342-1347. https:// dx.doi.org/10.1073/pnas.0605080104

29- Sutendra G, Michelakis ED. The metabolic basis of pulmonary arterial hypertension. Cell Metab 2014;19:558-573. https://dx.doi.org/10.1016/j. cmet.2014.01.004
30- Lombard DB, Chua KF, Mostoslavsky R, Franco S, Gostissa M, Alt FW. DNA repair, genome stability, and aging. Cell 2005;120:497-512. https://dx.doi. org/10.1016/j.cell.2005.01.028

31- Ou HL, Schumacher B. DNA damage responses and p53 in the aging process. Blood 2018;131:488-495. https://dx.doi.org/10.1182/blood-2017-07-746396

\section{Teşekkür}

$\mathrm{Bu}$ çalışma Üniversitemiz Bilimsel Araştırma Projeleri Koordinasyon Birimi tarafından 2016HZDP003 proje numarası ile desteklenmiştir. Makalenin içeriğinden ve yazılmasından tek başına yazarlar sorumludur. 1. ve 2. yazar eş katkı sağlamıştır. Çalışmanın bir kısmı Avrupa Kardiyoloji (Münih, Almanya, 2529 Ağustos 2018) ve Avrupa Fizyoloji (Londra, İngiltere, 14-16 Eylül 2018) kongrelerinde poster olarak sunulmuştur. 